\title{
Preliminary Study of Polysaccharide and Oligosaccharide Alginate (AOS) as Prebiotic of Probiotic Bacteria
}

\author{
Ervia Yudiati* Subagiyo and Muhammad Salauddin Ramadhan Djarod
}

\author{
Department of Marine Sciences, Faculty of Fisheries and Marine Sciences, Diponegoro University \\ Jl. Prof. Soedarto SH, Tembalang, Central Java, Indonesia \\ Email: eyudiati@gmail.com
}

\begin{abstract}
Synbiotics are related to pre and probiotic mixture which work synergically and provide the intestine microbial balance in organisms. This study aims to evaluate the potency of alginate polysaccharide and oligosaccharide (AOS) as prebiotic to probiotic bacteria originally from a commercial yogurt. Probiotic bacteria were plated to MRSA and incubated in $24 \mathrm{hrs}$. Over five isolated bacteria, three probiotic isolate bacteria were defined positively(C11; C14 and C15). The prebiotic test was done by culturing the isolate C14 to MRSB and incubated $24 \mathrm{hrs}$. After $24 \mathrm{hrs}$, all the MRSB liquid culture became turbid, showed a positive effect, except the MRSB culture without any alginate enrichment. Probiotic bacteria from MRSB were then plated into MRSA for Total Plate Count (TPC) test and incubated. TPS revealed that $0.1 \mathrm{mg} / \mathrm{mL}$ enriched AOS media resulted the highest number of probiotic bacteria $\left(1.193 \times 10^{5} \mathrm{CFU} / \mathrm{mL}\right)$ compared to enriched AOS and $0.05 \mathrm{mg}$ AOS $/ \mathrm{mL}$ media $\left(6 \times 10^{3} \mathrm{CFU} / \mathrm{mL}\right.$ ). These results have proven a high ability to develop AOS as prebiotic.
\end{abstract}

Keywords: Alginate, AOS, prebiotic, probiotic.

\section{INTRODUCTION}

Probiotic considered the most important bacteria dealing with pharmaceuticals such as anticarcinogenic effect (Shoukat et al., 2020) and food industries (Gayathri \& Rashmi., 2016; Bordoni et al., 2017). Probiotics serve both, either in dairy or non-dairy products. A recommendation has been proposed to regularly consumed food containing probiotic microorganisms. This is pointed to establish a positive balance of useful or beneficial microbes population in the intestinal flora in humans (Soccol et al., 2010) as well as animals including white shrimp Litopenaeus vannamei (Liv et al., 2014).

In marine organisms, especially in shrimp culture, researchers elucidate some findings concerning disease outbreak. To control this outbreak in shrimp culture, people used to apply chemotherapically by antibiotics and hormones (Li et al., 2018). This leads to antibiotic-resistant pathogens (Su et al, 2011) and harsh pollution to the environment (Holmström et al., 2003). The development and application of probiotics in marine culture have been raised rapidly. This needs to be done synergically to fulfill some needs such as the resistance of disease, growth factor, feed efficiency, and safety product for a human being (Ringø., 2020) as well as shrimp culture (Toledo et al., 2019).

Alginate is a natural compound from brown seaweed's cell wall (Yudiati \& Isnansetyo, 2017). Alginate was managed successfully to control the resistant pathogens. Research from Yudiati et al., (2016; 2019) and Lee at al., (2009) clearly described that alginate is an effective supplement to suppress replication of severe pathogenic bacteria and White spot Syndrome Virus Disease by improving the shrimp immune system and transcription of immune gene expression. Alginate oligosaccharide which produces form thermal heating (Yudiati et al, 2018) also enhanced the tolerance of Zebrafish in oxygen exposure tests (Yudiati et al, 2020).

Synbiotics is a mixture of prebiotics and probiotics. This effect will be beneficial to the 
host by the colonization of live microbial dietary supplements (Harpeni et al., 2017). Moreover, synbiotics have also been revealed to substitute and solve the antibiotic-resistant negative effects (Su et al., 2011). Besides, the combination prebiotics application could enhance the higher promotion of immune response and growth parameters of aquatic species (Li et al., 2018)

Afni et al., (2017) reported AOS produced enzymatically as prebiotics on shrimp culture. Even though, up to now, there is still limited information concerning alginate oligosaccharide as prebiotic for probiotic bacteria. Liu et al., (2009) investigated isomaltooligosaccharides from corn starch to improve the immune response and WSSV resistant to L. vannamei. Furthermore, Li et al., (2007) used commercial fructooligosaccharide as prebiotics for similar immune responses in shrimp. The basic information to prove the ability of alginate oligosaccharide (AOS) as prebiotics needs to be exposed. This present research aims to evaluate the potency of alginate polysaccharide and alginate oligosaccharide (AOS) to serve the probiotic bacteria isolated from a commercial yogurt.

\section{MATERIALS AND METHODS}

\section{Extraction of alginate and AOS production}

Sargassum sp. was collected from Teluk Awur waters, Jepara. This seaweed was then clean up from debris and salts, followed by dried up under room temperature. Seaweed was then blended to produce a powder. The powder was then extracted $24 \mathrm{hrs}$ with $5 \%$ $\mathrm{Na}_{2} \mathrm{CO}_{3}$, filtered. $0.13 \mathrm{M} \mathrm{KCl}$ was added, mixed well with cold ethanol absolute (1:1)(Yudiati \&lsnansetyo, 2017). Centrifugation at $3500 \mathrm{rpm}$ was administered in 5 minutes. Finally, the extract was then dried up at a dried cupboard $\left(60^{\circ} \mathrm{C}\right)$. Production of AOS was performed by thermal heating (Yudiati et al., 2018). This was done by heat up the alginate powder in the oven laboratory at $140^{\circ} \mathrm{C}$ for $4.5 \mathrm{hrs}$.

\section{Probiotic Bacteria Isolation}

Probiotic bacteria were isolated from commercial yogurt Cimory ${ }^{\circledR}$. This commercial brand using Lactic Acid Bacteria (https://cimory.com/. Furthermore, isolation on this probiotics was using MRSA (De Man Rogosa and Sharpe Agar) medium with CaCO3 addition. MRSA (De Man Rogosa and Sharpe Agar) and MRSB (De Man Rogosa and Sharpe Broth) were used as probiotic bacteria media. 3.12 gram MRSA media was mixed with $0.3 \mathrm{~g} \mathrm{CaCO}_{3}$, were then diluted with 60 $\mathrm{mL}$ aquadest. The solution was then homogenized and heat up with a hot plate. Sterilization was performed by autoclaving at $121^{\circ} \mathrm{C}$ in 20 minutes, poured into the petridish, and hardened. One $\mathrm{mL}$ of commercial yogurt was plated into MRSA solid media, incubated at room temperature for $24 \mathrm{hrs}$. Some selection had been done to the grown bacteria colony which produce the clear zone. This acid produced colony was assumed as probiotics bacteria. Yogurt uses lactic acid probiotic bacteria for fermentation.

\section{Alginate polysaccharides and AOS Prebiotic Test}

Test of Alginate polysaccharide and AOS was done separately. Each different alginate was set up. This was initially performed by diluted $2.96 \mathrm{~g}$ of MRBS in $57 \mathrm{~mL}$ aquadest, sterilized similarly as above. The liquid MRSB was then poured into four tubes according to the treatments. The four treatments were: control, MRSB $+0.05 \mathrm{mg} / \mathrm{mL}$ (alginate and AOS), MRSB $+0.1 \mathrm{mg} / \mathrm{mL}$ (alginate and $A O S$ ), and MRSB $+0.2 \mathrm{mg} / \mathrm{mL}$ (alginate and $A O S$ ). Prebiotic bacteria from the yogurt was then inoculated, incubated on a shaker for $24 \mathrm{hrs}$, at speed of $120 \mathrm{rpm}$ in room temperature. The observation on growth was done quantitatively based on media turbidity. TPC was also done to determine quantitatively.

\section{Total Plate Count (TPC)}

24 hrs of cultured probiotic bacteria from MRSB enriched with AOS were then continued to the TPC test. TPC was done in pour plate methods and only done to the AOS treatment enriched in different alginate concentration. $7.8 \mathrm{~g}$ MRSA media and $0.75 \mathrm{~g}$ $\mathrm{CaCO} 3$ were prepared and diluted with 150 $\mathrm{mL}$ aqua dest. Those were then heated up in a hot plate at $130 \mathrm{rpm}$ and sterilized. The sterile media were then poured into the petridish, leave until hardened. The probiotic bacteria from the MRSB were then plated into 
solid MRSA. Incubation was administered in 24 hrs and the total bacteria in each petridish was then counted.

\section{RESULTS AND DISCUSSION}

\section{Probiotic Bacteria Isolation}

There were some probiotic bacteria isolates from Cimory ${ }^{\circledR}$ commercial yogurt. The characterization of probiotic bacteria isolation was presented in Table 1. There were three positive probiotic bacteria found in commercial yogurt. This bacteria predicted as probiotic bacteria. Probiotics bacteria in Cimory ${ }^{\circledR}$ yogurt were composed of Lactobacillus bulgaricus \& Streptococcus thermopillus (https://cimory.com/). It has been reported by Banda et al., (1992) which use Lactobacillus bulgaricus as probiotic to Turbot (Scophthalmus maximus L.). Additionally, Streptococcus thermophile has also been reported as Turbot larvae for their probiotics (Gatesoupe, 1991). While in food industries the most commonly used strains are the genera of Lactobacillus, Carnobacterium Pediococcus, Enterococcus, Lactococcus
Streptococcus, Aerococcus, as well as Bifidobacterium (Holzapfel \& Wood., 2014). Prebiotics is not digestible in the host's enzyme. On the other hand, prebiotic provide substrates to promote the growth of probiotics bacteria (Shoukat et al., 2020).

\section{Prebiotic Test of Alginate Polysaccharides and AOS}

The results of the prebiotic test on different alginate are shown in Table 2. Based on results, it can be seen that the best qualitative test of alginate prebiotic is from the MRSB media with $0.05 \mathrm{mg} / \mathrm{mL}$ poly and oligosaccharide alginate enrichment. Addition of 0.05 alginate, both poly and oligosaccharide gave higher turbidity. Therefore Indicates higher intensity, compared to different alginate addition. The prebiotic test without any alginate addition was negative.

Harpeni et al., (2017) reported that they used sweet potato starch which contains sucrose and raffinose. Liu et al., (2018) used commercial mannan oligosaccharide and

Table 1. Characterization of probiotic isolated bacteria

\begin{tabular}{lllllll}
\hline Bacteria Code & Colour & Shape & Elevation & Surface & Margin & $\begin{array}{c}\text { Acid } \\
\text { production }\end{array}$ \\
\hline C11 & Pink & Circular & Raised & Smooth, shiny & Entire & Positive \\
C12 & $\begin{array}{l}\text { Fade } \\
\text { cream }\end{array}$ & Circular Convex & Smooth, shiny & Entire & Negative \\
C13 & $\begin{array}{l}\text { White } \\
\text { cream }\end{array}$ & Circular & Raised & Smooth, shiny & Entire & Negative \\
C14 & $\begin{array}{l}\text { Fade } \\
\text { cream }\end{array}$ & Circular & Convex & Smooth, shiny & Entire & Positive \\
C15 & $\begin{array}{l}\text { Fade } \\
\text { cream }\end{array}$ & Circular & Convex & Smooth, shiny & Entire & Positive \\
\hline
\end{tabular}

Note : Positive: Probiotic bacteria-produced acid compound; Negative: Probiotic bacteria was not produced acid compound

Tabel 2. Prebiotic test of alginate poly and oligosaccharide from different concentration

\begin{tabular}{llcc}
\hline \multirow{2}{*}{ Concentration } & \multicolumn{2}{l}{ Alginate } & Oligosaccharide \\
\cline { 2 - 4 } & Polysaccharide & & - \\
\hline $0 \mathrm{mg} / \mathrm{mL}$ & - & ++ \\
$0.05 \mathrm{mg} / \mathrm{mL}$ & ++ & + \\
$0.1 \mathrm{mg} / \mathrm{mL}$ & + & + \\
$0.2 \mathrm{mg} / \mathrm{mL}$ & + & + \\
\hline
\end{tabular}

Note : - = undetermined (transaparent); + = grow well (turbid); ++ : grow fast (much more turbid) 
inulin which improve growth, gene immune expression, and resistance to Vibrio alginolyticus and WSSV. Moreover, Li et al., (2007) applied fructooligosaccharides (FOS) while isomaltooligosaccharide (MOS) has been investigated by $\mathrm{Li}$ et al., (2009). Thin Layer Chromatography (TLC) and Fourier Transform Infra-Red Spectroscopy has been clearly defined that alginate from Sargassum siliquosum which also applied in this present research, is characterized by mannuronate and guluronate monosaccharide (Yudiati et al., 2017; Yudiati et al., 2016). Based on the results, this present study revealed that alginate monosaccharide was degraded and digested by probiotic bacteria, strengthened to research by Afni et al., (2017), using AOS from brown seaweed Sargassum crassifolium.

\section{Total Plate Count Test of Probiotic Bacteria C15}

Total probiotic bacteria colony grown on different AOS concentrations can be seen in Table 3. Results show that the highest colony form of probiotic bacteria was MRSA enriched with $0.1 \mathrm{mg} \mathrm{AOS} / \mathrm{mL}$. The MSRA 0 $\mathrm{mg} / \mathrm{mL}$ and MRSA enriched with $0.05 \mathrm{mg} / \mathrm{mL}$ showed similar results. TPC test was used to ensure the qualitative prebiotic test. The results of TPC was not exactly fit for the previous test. This, hypothetically caused by the growth of bacteria pattern. TPC was done after 24 hrs incubation in MRSB media. The bacteria were plated after 24 hrs incubation and then determined. At this stage, probiotic bacteria reach the stationary phase, so the growth rate was diminishing. The peak exponentially growth was not well observed. Furthermore, there were some probiotic bacteria grown in MRSA media without any alginate. In fact, the MRSB also contains dextrose. In the late phase, probiotic bacteria were also grown. Our suggestion is to observe

Table 3. TPC of $\mathrm{C} 15$ in MRSA enriched with AOS in different concentration

\begin{tabular}{ll}
\hline AOS concentration & Total colony $\left(\mathrm{cfu} / \mathrm{mL}^{-1}\right)$ \\
\hline $0 \mathrm{mg} / \mathrm{mL}$ & $6 \times 10^{3}$ \\
$0.05 \mathrm{mg} / \mathrm{mL}$ & $6 \times 10^{3}$ \\
$0.1 \mathrm{mg} / \mathrm{mL}$ & $1.193 \times 10^{5}$ \\
$0.2 \mathrm{mg} / \mathrm{mL}$ & - \\
\hline
\end{tabular}

and determine the TPC in certain repeatable hours to get the complete curve growth of bacteria

The application of a prebiotic agent is a dose-dependent manner. Research by $\mathrm{Li}$ et al., 2018 applicated MOS in different concentrations and proofed that probiotic bacteria have specific preferences. This present study demonstrates that probiotic bacteria from commercial local yogurt prefer media enriched with $0.1 \mathrm{mg}$ AOS $/ \mathrm{mL}$ MRS media. At last, TPC of $0.1 \mathrm{mg}$ AOS enriched has still resulted in the best performance $\left(1.193 \times 10^{5} \mathrm{CFU} / \mathrm{mL}\right)$ compare to other treatments.

\section{CONCLUSION}

Based on the results it can be concluded that AOS has a good potency of being prebiotic to provide nutrition for probiotic bacteria. The best AOS concentration is $0.1 \mathrm{mg} / \mathrm{mL}$ media (TPC $=1.193$ $\times 10^{5} \mathrm{CFU} / \mathrm{mL}$. This basic research is expected to be the basic information for exploring the AOS for further function both in humans and animals.

\section{ACKNOWLEDGEMENT}

This research was fully supported financially by Applied Superior Research Grant of the Ministry of Research and Higher Education (DRPM). Assigned by contract no 101-98/UN7.P4.3/PP/2018, dated February 5th, 2018.

\section{REFERENCES}

Afni, F.S., Purwaningsih, S., Nurilmala, M. \& Peranginangin, R. 2017. Production of Alginate Oligosaccharides (AOS) as Prebiotic Ingredients through by Alginate lyase enzyme. J. Pengolah. Hasil Perikan. Indo., 20(1):109-122. doi: 10.17844/jphpi. v20i1.16498

Bordoni, A., Danesi, F., Dardevet, D., Dupont, D., Fernandez, A.S., Gille, D., Nunes dos Santos, C., Pinto, P., Re, R., Rémond, D. \& Shahar, D.R., 2017. Dairy products and inflammation: A review of the clinical evidence. Critical Rev, Food Technol. 57:2497-2525 . doi: 10.1080/10408398.201 4.967385 
Banda, G., Chereguini, I. \& Rasines, O. 1992. Influence of lactic bacterial additives on turbot (Scophthalmus maximus L.) larvae culture. Bol. Inst. Esp. Oceanogr. 8:247254.

Gatesoupe, F.J. 1991. The effect of three strains of lactic bacteria on the production rate of rotifers, Brachionus plicatilis, and their dietary value for larval turbot, Scophthalmus maximus. Aquaculture 96: 335-342. doi: 10.1016 10044-8486(91)90162-Z

Gayathri D, \& Rashmi, B. 2016. Anti-Cancer Properties of Probiotics: A Natural Strategy 597 for Cancer Prevention. EC Nutrition 5:1191-1202

Harpeni, E., Santoso, L., Supomo., Wardiyanto., Widodo, A. \& Yolanda, L. 2017. Effects of Dietary Probiotic Bacillus sp. D2.2. and Prebiotic Sweet Potato Extract on Growth Performance and Resistance to Vibrio harveyi in Pacific White Shrimp, Litopenaeus vannamei. Aquacul. Indo. 18(2):55-61. doi: 10.21534 /ai.v/8i2.107

Holmström, K., Gräslund, S., Wahlström, A., Poungshompoo, A., Bengtsson, B.E., \& Kautsky, N. 2003. Antibiotic use in shrimp farming and implications for environmental impacts and human health. Int. J. Food Sci. Technol. 38: 255266. doi: 10.1046/j.1365-2621.2003.00671.x

Holzapfel, W.H, \& Wood, B.J. 2014. Lactic acid bacteria: biodiversity and taxonomy. John Wiley \& Sons.

Li J., Tan, B. \& Mai. K, 2009. Dietary probiotic Bacillus OJ and isomaltooligosaccharides influence the intestine microbial populations, immune responses, and resistance to white spot syndrome virus in shrimp (Litopenaeus vannamei). Aquacult. 291:35-40. doi: 10.1016/j.aquaculture.2009 03.005

Ringø, E. 2020. Probiotics in shellfish aquaculture, Aquacul. Fish., 5 (1):1-27. doi: 10.1016/j.aaf.2019.12.001

Shoukat, S., 2020. Potential anti-carcinogenic effect of probiotics and lactic acid bacteria in detoxification of benzo[a]pyrene: A Review. Trends. Food Sci. Technol., 99:450-459. doi: 10.1016/j.tifs. 2020.02.029
Soccol, C.R., Vandenberghe, L.P.S., Spier, M.R., Medeiros, A.B.P., Yamaguishi, C.T., Lindner, J.D.D., Pandey, A. \& ThomazSoccol, V. 2010. The Potential of Probiotics: A Review. Food Technol. Biotechnol. 48(4):413-434

Su H.C., Ying, G.G., Tao, R., Zhang, R.Q., Fogarty, L.R. \& Kolpin, D.W. 2011. Occurrence of antibiotic resistance and characterization of resistance genes and integrons in Enterobacteriaceae isolated from integrated fish farms in South China. J. Environ. Monit. 13:3229-3236. doi: 10.1039/clem10634a

Toledo, A., Frizzo, L., Signorini, M., Bossier, P. \& Arenal, A. 2019. Impact of probiotics on growth performance and shrimp survival: A meta-analysis, Aquaculture 500: 196205. doi: 10.1016/j.aquaculture.2018.10. 018

Yudiati, E, \& Isnansetyo, A. 2017. Characterizing the Three Different Alginate Type of Sargassum siliquosum. IImu Kelautan: Indo. J. Mar. Sci. 22(1):714. doi: 10.14710/ik.jjms. 22.1.7-14

Yudiati, E., Pringgenies, D., Djunaedi, A., Arifin, Z., \& Sudaryono, A. 2018. Free radical Scavenging of Low Molecular Weight Sodium Alginate (LMWSA) from Sargassum polycystum Produced by Thermal Treatment. Aquac. Ind., 19(1): 21-27. doi: 10.21534/ai.v19il.121

Yudiati, E., Isnansetyo, A., Murwantoko, Triyanto, \& Handayani, C.R. 2019. Alginate from Sargassum siliquosum Simultaneously Stimulates Innate Immunity, Upregulates Immune Genes, and Enhances Resistance of Pacific White Shrimp (Litopenaeus vannamei) Against White spot Syndrome Virus (WSSV). Mar. Biotechnolog. 21 (4):503-514. doi: 10.1007/s10126-019-09898-7

Yudiati, E., Rustadi., F.I. Ginzel., J.R. Hidayati., M.S. Rizfa., N. Azhar., M.S.R. Djarod., E. Heriyati., \& R. Alghazeer. 2020. Oral Administration of Alginate Oligosaccharide from Padina sp. Enhances Tolerance of Oxygen Exposure Stress in Zebrafish (Danio rerio). Ilmu Kelautan: Indo. J. Mar. Sci. 25(1):7-14. doi: 10.14710/ik.ijms.25.1.714 